CPB Netherlands Bureau for Economic

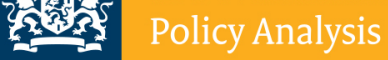

\title{
A structural analysis of labour supply and involuntary unemployment in the Netherlands
}





\title{
A structural analysis of labour supply and involuntary unemployment in the Netherlands
}

\author{
Henk-Wim de Boer*
}

September 16, 2015

\begin{abstract}
Most structural models for labour supply ignore the possibility of involuntary unemployment which may lead to biased behavioural responses. This may have important policy implications. We estimate a structural model for labour supply without and with involuntary unemployment for the Netherlands, using data for the period 20062009. We estimate both models for four groups separately: singles without children, single parents, couples without children and couples with children. We use information on job search behaviour to estimate the determinants of involuntary unemployment. We find that average labour supply elasticities are only slightly lower in the model with involuntary unemployment than in the model without involuntary unemployment. The main reason for this small bias is the relatively small share of individuals who are involuntary unemployed in the period 2006-2009. A simulation of tax-benefit reforms confirms that the upward bias in average labour supply responses is limited in the model without involuntary unemployment. Only for subgroups with a high risk of being involuntary unemployed, such as lower educated individuals and immigrants, we find a relatively large upward bias in labour supply elasticities in the model without involuntary unemployment.
\end{abstract}

JEL classification codes: C25, C52, H31, J22

Keywords: Discrete choice models, household labour supply, involuntary unemployment

${ }^{*}$ CPB Netherlands Bureau for Economic Policy Analysis and VU University Amsterdam. P.O. Box 80510, 2508 GM The Hague. Email: H.W.de.Boer@cpb.nl. Phone: +31-70-3386152. I have benefitted from comments and suggestions by Leon Bettendorf, Hans Bloemen, Johannes Hers, Egbert Jongen, Arjan Lejour and participants of IIPF 2014 in Lugano and EALE 2014 in Ljubljana. Remaining errors are my own. 


\section{Introduction}

Most structural models for labour supply assume that individuals freely choose their preferred alternative from a fixed discrete choice set. Examples include Bargain et al. (2014), Blundell and Shephard (2012), Keane and Moffitt (1998) and Van Soest (1995). In reality, demand side restrictions may limit these discrete choice sets. This may have important policy implications. Consequently, the employment, budgetary and welfare effects of changes in financial incentives, e.g. changes in welfare benefits and in-work tax credits, may be quite different once we account for the possibility that individuals or households can not realize their preferred labour supply (Bargain et al., 2010).

This paper examines the role of involuntary unemployment in the Netherlands. We compare the behavioural responses of different subgroups in the model with involuntary unemployment with those responses in the standard labour supply model without rationing. By simulating several tax-benefit reforms, we consider to what extent different tax reforms lead to different labour supply responses when we account for involuntary unemployment. It is also interesting to investigate whether these differences are more prominent for individuals with a higher probability of being involuntary unemployed, such as lower educated individuals and immigrants.

We use information from the Labour Market Panel of Statistics Netherlands for the period 2006-2009 to estimate a structural model for labour supply with involuntary unemployment. Next to information on wages and hours worked for the employed the data set also contains information on job search behaviour by the non-employed. With this information we can estimate the separate roles of preferences and job opportunities in the determination of employment outcomes, using the double-hurdle model developed by Cragg (1971). Next, we extend the model for singles and single parents with endogenous job search behaviour, where job search behaviour depends on the expected benefit from this search (Pissarides, 2000).

Our main findings are as follows. First, the average labour supply elasticities are only slightly lower in the model with involuntary unemployment than in the model without involuntary unemployment. By contrast, the incorporation of involuntary unemployment makes a much bigger difference in the labour supply effects of tax-benefit reforms in related studies (Bargain et al., 2010). The main reason for this small impact of incorporating involuntary unemployment on behavioural responses is the small share of individuals reporting that they are involuntary unemployed in our data set. ${ }^{1}$ This analysis provides

\footnotetext{
${ }^{1}$ Although this paper uses a rather broad definition of involuntary unemployment (i.e. whether an individual actively searched for a job in the past six months), only $3 \%$ of individuals living in couples, $6 \%$ of singles without children and $8 \%$ of single parents are involuntary unemployed.
} 
evidence that the standard labour supply model, in which rationing does not exist, gives a good prediction of labour supply responses for other countries with low unemployment, such as Germany (5\%), Japan (3.6\%), Korea (3.5\%) and Norway (3.5\%) in 2014 (OECD, 2014). We do however find a relatively large upward bias in labour supply elasticities for subgroups who have a relatively high risk at being involuntary unemployed, such as lower educated individuals and non-Western immigrants, in the model without involuntary unemployment. Second, a simulation of tax-benefit reforms shows that the upward bias in aggregated labour supply responses is also limited for the reforms we consider. Third, introducing endogenous job search behaviour in the model with involuntary unemployment for singles and single parents slightly reduces their labour supply responses further.

We follow earlier work by Bargain et al. (2010), Blundell et al. (1987), Euwals and Van Soest (1999) and Hogan (2004). This paper contributes to the literature in the following ways. First, we use a large and rich data set which enables us to estimate several subgroups separately. We estimate the parameters of the utility function separately for singles, single parents, couples without children and couples with children. This makes the estimation more flexible and precise. However, many studies on labour supply with involuntary unemployment pool subgroups due to the low number of observations and focus at a particular group. For instance, Blundell et al. (1987), Hogan (2004) and Laroque and Salanie (2002) focus on women, whereas Euwals and Van Soest (1999) focus on single men and single women. Only Bargain et al. (2010) estimates singles and couples separately but they pool households without and with children due to the low number of observations. Our analysis shows this distinction is important because these subgroups respond differently to financial incentives. In addition, our large data set enables us to give a detailed overview of the heterogenous behavioural responses of individuals based on characteristics such as education and ethnicity. As it turns out, these differences are substantial. Second, our data set contains large reforms on in-work tax credits in 2006-2009 that generate exogenous variation in the budget constraints. This benefits the identification of our structural parameters. By contrast, Bargain et al. (2010) rely on cross-section data. Furthermore, we use four consecutive years which gives us variation in job search behaviour. Third, we extend our model with involuntary unemployment by explictly modeling job search behaviour. Structural labour supply models with involuntary unemployment treat job search behaviour as exogenous (Bargain et al., 2010; Euwals and Van Soest, 1999), which is a restriction. By making job search endogenous, we show that policy measures that increase work incentives, result in individuals shifting from the group of non-searchers to searchers. We take a broad definition of involuntary unemployment to include discouraged workers. This group is becoming increasingly important. Krueger et al. (2014) for 
instance show that long-term unemployment is decreasing quickly in the U.S. but this is partly due to long-term unemployed withdrawing from the labour force. This paper shows that a reform, such as lowering benefits, induces discouraged workers to re-enter the labour force. However, the total effect on labour supply is limited, at least in the Netherlands.

The paper is organized as follows. Section 2 sets out the structural model. Section 3 describes the data set we use in our estimation. Section 4 then presents the estimation results, the fit of the model and the simulated labour supply elasticities. In Section 5 we consider what difference accounting for involuntary unemployment makes in a number of policy simulations. Section 6 extends the model with involuntary unemployment for singles and single parents by allowing for endogenous job search. Section 7 discusses some limitations of the analysis and concludes.

\section{Structural model}

We specify a structural model for labour supply, in which the choice of working hours is governed by preferences, the budget constraint, and the probability of job offers. We first consider the specification of preferences and the budget constraint, and subsequently consider the job offer probability.

\subsection{Model with involuntary unemployment and exogenous job search}

Households choose their preferred combination of hours of work and leisure from a finite set of alternatives: $j \in\{1, \ldots, J\}$, where $J=6$ for singles and $J=36$ for couples. Households maximize their utility, subject to a budget constraint and a time constraint. We assume a log quadratic utility function, which is a flexible specification that allows for a good fit of the observed hours distribution. Specifically, the utility function for couples is given by the random utility function

$$
\begin{aligned}
U\left(y, h_{m}, h_{f}, f c_{m}, f c_{f} ; \boldsymbol{X}\right)= & u\left(y, h_{m}, h_{f}, f c_{m}, f c_{f} ; \boldsymbol{X}\right)+\epsilon \\
= & \beta_{1} y+\beta_{2}(\boldsymbol{X}) h_{m}+\beta_{3}(\boldsymbol{X}) h_{f}+ \\
& \beta_{4} y^{2}+\beta_{5} h_{m}^{2}+\beta_{6} h_{f}^{2}+ \\
& \beta_{7} y h_{m}+\beta_{8} y h_{f}+\beta_{9} h_{m} h_{f}+ \\
& \beta_{10}(\boldsymbol{X}) f c_{m}+\beta_{11}(\boldsymbol{X}) f c_{f}+\epsilon,
\end{aligned}
$$

where $y$ denotes the log of real weekly income, $h_{m}$ and $h_{f}$ denote the log of hours of leisure per week for men $m$ and women $f$ respectively, and $\epsilon$ denotes a household-option specific random term which is assumed to be extreme value (type-I) distributed. This results in 
the familiar multinomial logit specification for the preferred labour supply probabilities, see McFadden (1974). The marginal utility of leisure is allowed to vary with individual and household characteristics $X .{ }^{2}$ We also include fixed costs of work for men and women, $f c_{m}$ and $f c_{f}$, as indicator variables which equal 0 in the non-working alternative and 1 in all the working alternatives, otherwise the model predicts too many individuals working only a few hours per week (Van Soest, 1995). Fixed costs of work represent disutility from work such as travelling costs, search costs or market frictions.

The budget constraint is given by

$$
y=w_{m} l_{m}+w_{f} l_{f}-T\left(w_{m} l_{m}, w_{f} l_{f} ; \mathbf{X}\right)
$$

where $w$ denotes the gross hourly wage and $l$ denotes hours worked per week. $T($.$) repre-$ sents taxes. The time constraint is given by

$$
l_{i}+h_{i} \leq T C
$$

where $T C=168$ hours. $^{3}$

The probability of involuntary unemployment is modelled as a standard probit:

$$
I_{i}=\Phi\left(\beta \boldsymbol{X}_{\boldsymbol{i}}\right)+v_{i}
$$

We first estimate the determinants of the probability that an individual is rationed (parameters $\beta$ ), given the demographic characteristics, using the involuntary unemployed and the employed. We then use this information to simulate an individual probability of involuntary unemployment $(\Phi)$ for all individuals in our sample. Given the simulated probability of rationing we can form the likelihood to estimate preferences over income and leisure.

For simplicity we outline the model for singles. ${ }^{4}$ For singles, there are three possible states on the labour market: i) voluntary unemployment, individual prefers not to work, ii) involuntary unemployment, individual prefers to work but does not have a job opportunity, and iii) employed, individual prefers to work and does have a job opportunity. ${ }^{5}$ Our approach builds heavily on the approach by Bargain et al. (2010) and we have the following

\footnotetext{
${ }^{2}$ We include a third order term for leisure in the specification (which is significant at the $1 \%$ level) to improve the fit of the model.

${ }^{3}$ Experimentation with other time endowments hardly affected our results.

${ }^{4}$ Derivation of the model for couples is similar and included in Appendix A

${ }^{5}$ Note that our definition of 'unemployment' includes non-participants.
} 
probabilities for being in state i), ii) and iii): ${ }^{6}$

$$
\begin{gathered}
P_{i}^{V O L}=\operatorname{Pr}\left(d_{i}=0\right)=\frac{\exp \left(U_{i 1}\right)}{\sum_{j=1}^{J} \exp \left(U_{i j}\right)}, \\
P_{i}^{I N V O L}=\operatorname{Pr}\left(d_{i}>0, p_{i}=0\right)=\Phi(\beta \boldsymbol{X}) \sum_{k=2}^{J}\left\{\frac{\exp \left(U_{i k}\right)}{\sum_{j=1}^{J} \exp \left(U_{i j}\right)}\right\},
\end{gathered}
$$

and

$$
P_{i, k \geq 2}^{E M P}=\operatorname{Pr}\left(d_{i}>0, p_{i}>0\right)=(1-\Phi(\beta \boldsymbol{X}))\left\{\frac{\exp \left(U_{i k}\right)}{\sum_{j=1}^{J} \exp \left(U_{i j}\right)}\right\} .
$$

The contribution of the voluntary unemployed to the likelihood function is straightforward and equals the probability of the observed choice, which is the logit probability that zero working hours has the highest utility (5). Involuntary unemployed individuals prefer another alternative than the observed outcome. Unfortunaly we do not have information on their preferred number of hours, so we only know that they want to participate and that one of the working alternatives is preferred. Their contribution to the likelihood is the sum of the probabilities of all positive hours values from the choice set, multiplied by the probability of involuntary unemployment (6). ${ }^{7}$ Finally, the contribution of an employed individual to the likelihood function equals the probability of the observed choice multiplied by the probability that the individual is not rationed on the labour market (7).

For workers we use observed gross wages whereas for non-workers we simulate wages. We model unobserved heterogeneity with respect to leisure by including Halton random draws in vector $\mathrm{X}$ for leisure. ${ }^{8}$ Taking 50 draws $(R)$ from the estimated wage distribution and 50 halton draws for unobserved heterogeneity, we maximize the following simulated likelihood for singles: ${ }^{9}$

\footnotetext{
${ }^{6}$ An alternative way to model demand side restrictions is to use a sampling technique, see Aaberge et al. (1999); Aaberge and Colombino (2009). They draw wages and hours from a market distribution. However, they do not have information on job search behaviour at the individual level.

${ }^{7}$ For workers, we use actual working hours. In reality, the preferred number of working hours may differ from the actual hours for workers as well. For instance, Bargain et al. (2010) and Euwals and Van Soest (1999) use desired hours instead of actual working hours. We do not observe desired hours in our dataset. And, more importantly, we believe this effect is limited in the Netherlands. Data from the OECD (2013) shows that only $5 \%$ of women working in part-time would like to work more hours, whereas this share is much higher in other OECD countries (13\% in Germany, $28 \%$ in France and 55\% in Spain).

${ }^{8}$ Halton draws provide us with a better coverage than pseudo-random draws for a finite sample (Creedy and Kalb, 2005).

${ }^{9}$ We derive the likelihood contributions for couples in a similar way.
} 


$$
\begin{aligned}
L & =\prod_{i \in V O L} \frac{1}{R} \sum_{r=1}^{R} \frac{\exp \left(U_{i 1 r}\right)}{\sum_{j=1}^{J} \exp \left(U_{i j r}\right)} \\
& \times \prod_{i \in I N V O L} \frac{1}{R} \sum_{r=1}^{R} \Phi(\beta \mathbf{X}) \sum_{k=2}^{J} \frac{\exp \left(U_{i k r}\right)}{\sum_{j=1}^{J} \exp \left(U_{i j r}\right)} \\
& \times \prod_{i \in E M P, k \geq 2} \frac{1}{R} \sum_{r=1}^{R}(1-\Phi(\beta \mathbf{X})) \frac{\exp \left(U_{i k r}\right)}{\sum_{j=1}^{J} \exp \left(U_{i j r}\right)}
\end{aligned}
$$

\subsection{Model with involuntary unemployment and endogenous job search}

We extend the model with involuntary unemployment for singles and single parents with endogenous job search behaviour. ${ }^{10}$ We follow Pissarides (2000) by making job search behaviour depend on the expected benefit from this search. ${ }^{11}$ Lowering welfare benefits makes labour force participation more attractive. Consequently, we may expect individuals to increase their job search effort as its potential reward increases. Suppose that utility $U(y, h, s)$ now depends on income $(y)$, hours of work $(h)$ and a dummy variable $(s)$ indicating whether the individual actively searches for a job $(s=1)$ or not $(s=0) .{ }^{12}$ Now we have the following possible outcomes:

1) The individual does not search, and receives utility:

$$
U_{i 1 r s}=u_{i 1 r 0}(y, h, f c ; \boldsymbol{X})+\epsilon
$$

2) The individual searches but does not find employment, and receives utility:

$$
U_{i 1 r s}-s c=u_{i 1 r 1}(y, h, f c ; \boldsymbol{X})-s c+\epsilon
$$

3) The individual searches, finds a job, chooses alternative $k$, and receives utility:

$$
U_{i k r s}-s c=u_{i k r 1}(y, h, f c ; \boldsymbol{X})-s c+\epsilon
$$

where $s c$ represents search costs and $k=2, . ., J$.

\footnotetext{
${ }^{10}$ We abstract from on the job search.

${ }^{11}$ However, our approach differs in other important aspects from the approach by Pissarides (2000). Pissarides (2000) for instance uses search and matching theory to study the labour market in a macroeconomic setting.

${ }^{12}$ Search costs lower utility.
} 
An individual only searches for a job if the expected benefit from search is higher than its cost. So for outcome 1 we have:

$$
U_{i 1 r s}>(1-\Phi(\beta \boldsymbol{X}))\left(E\left[U_{i k r s}\right]-s c\right)+\Phi(\beta \boldsymbol{X})\left(U_{i 1 r s}-s c\right)
$$

where the expected utility from work, $E\left[U_{i k r s}\right]$, equals:

$$
E\left[U_{i k r s}\right]=\sum_{k=2}^{J} \frac{\exp \left(U_{i k r s}\right)}{\sum_{j=1}^{J} \exp \left(U_{i j r s}\right)} U_{i k r s} .
$$

The probability than an individual does not search then becomes:

$$
\operatorname{Pr}(s=0)=\frac{\exp \left(U_{i 1 r s}\right)}{\exp \left(U_{i 1 r s}\right)+\exp \left\{\Phi(\beta \boldsymbol{X})\left(U_{i 1 r s}-s c\right)+(1-\Phi(\beta \boldsymbol{X}))\left(E\left[U_{i k r s}\right]-s c\right)\right\}}
$$

Individuals in situation 2 and 3 search for a job, so the search condition is fullfilled: $\operatorname{Pr}(s=1)=1-\operatorname{Pr}(s=0)$. The probability that an individual searches depends on the expected benefit of this search. Then, there are two reasons why an individual, who searches, does not work in this situation. Firstly, he did not receive a job offer with probability $\Phi(\beta \boldsymbol{X})$. Secondly, he did receive a job offer but utility of the working option is too low compared to the non-working option. In this case, the individual prefers not working over the working alternatives. Hence, the probability of outcome 2 is:

$$
\operatorname{Pr}(s=1)\left\{\Phi(\beta \boldsymbol{X})+(1-\Phi(\beta \boldsymbol{X})) \frac{\exp \left(U_{i 1 r s}\right)}{\sum_{j=1}^{J} \exp \left(U_{i j r s}\right)}\right\}
$$

For individuals in situation 3 the search condition holds and these individuals prefer one of the working alternatives $(k>1)$. This happens with probability:

$$
\operatorname{Pr}(s=1)(1-\Phi(\beta \boldsymbol{X})) \frac{\exp \left(U_{i k r s}\right)}{\sum_{j=1}^{J} \exp \left(U_{i j r s}\right)}
$$

We only estimate the model with endogenous job search for singles and single parents and not for couples. The reason for this is twofold. First, the model with endogenous job search is numerically challenging as the likelihood function becomes more complex, especially for couples (see below). Second, the share of involuntary unemployment is relatively high among singles and single parents. Involuntary unemployment is less of a problem among couples, see section 3. For singles we arrive at the following likelihood: 


$$
\begin{aligned}
L & =\prod_{i \in V O L} \frac{1}{R} \sum_{r=1}^{R} \operatorname{Pr}(s=0) \\
& \times \prod_{i \in I N V O L} \frac{1}{R} \sum_{r=1}^{R} \operatorname{Pr}(s=1)\left\{\Phi(\beta \boldsymbol{X})+(1-\Phi(\beta \boldsymbol{X})) \frac{\exp \left(U_{i 1 r s}\right)}{\sum_{j=1}^{J} \exp \left(U_{i j r s}\right)}\right\} \\
& \times \prod_{i \in E M P} \frac{1}{R} \sum_{r=1}^{R} \operatorname{Pr}(s=1)(1-\Phi(\beta \boldsymbol{X})) \frac{\exp \left(U_{i k r s}\right)}{\sum_{j=1}^{J} \exp \left(U_{i j r s}\right)}
\end{aligned}
$$

\section{Data}

We use the Labour Market Panel (LMP, Arbeidsmarktpanel in Dutch) of Statistics Netherlands (2012) for the period 2006-2009. The LMP is a large administrative household panel data set and contains a rich set of individual and household characteristics, including gender, month and year of birth, the level of education and ethnicity for all adult members of the household, the ages of the children and the area of residence. The LMP also contains administrative data on hours worked and gross income from different sources (wages, profits, benefits etc.). Statistic Netherlands enriched the LMP with data from the Labour Force Survey of Statistics Netherlands (2009) (LFS, Enquete Beroepsbevolking in Dutch). In the LFS, we have information on job search behaviour for one year at the individual level, within the period 2006-2009. That is, we can only identify whether individuals are involuntary unemployed for the year in which these individuals were interviewed in the LFS.

We apply several selection criteria. We exclude households with missing individual or household characteristics. We exclude self-employed individuals because we do not observe their working hours. ${ }^{13}$ We also exclude individuals with disability benefits since we do not observe whether these individuals are temporary or permanently disabled. Finally, we exclude individuals with multiple sources of income (for example wages and profits) because we cannot determine their budget set.

Table 1 shows descriptive statistics of the subgroups we consider, where groups are defined by the age of the youngest child. Households with children have a youngest (dependent) child up to 18 years of age. We use the full sample for singles (without children) and single parents. The participation rate (86\%) and the average number of working hours (35.6 hours per week) are relatively high for singles. ${ }^{14}$ Single parents

\footnotetext{
${ }^{13}$ This approach is common in the labour supply literature (Bargain et al., 2014; Blundell and Shephard, 2012).

${ }^{14}$ Excluding individuals who do not work.
} 
participate less on the labour market $(71 \%)$ and the average number of working hours per week is relatively low (29.6 hours per week). Furthermore, women (84\%), non-Western immigrants (26\%) and lower educated individuals (34\%) form a relatively large group in the sample for single parents compared to singles without children.

Over the period 2006-2009, $4.5 \%$ of the individuals in our sample is involuntary unemployed. We label individuals as involuntary unemployed when they have actively searched for a job in the past 6 months. Hence, we use a broad definition of involuntary unemployment to include discouraged workers. ${ }^{15,16}$ The share of involuntary unemployed is $5 \%$ for singles and $8 \%$ for single parents, whereas the share of voluntary unemployed is $9 \%$ and $21 \%$ respectively.

For couples, we use a randomly drawn subsample in order to limit the computational burden of the estimation. ${ }^{17}$ Nearly all men in couples participate on the labour market, their share of involuntary unemployment is small (1\%), and their average number of working hours is high (approximately 38 hours per week). Women in couples participate less: $75 \%$ and $77 \%$ for women without children and women with children, respectively. The average number of working hours per week, conditional on participation, is lower for mothers with children (22.8 hours per week) than for mothers without (28.2 hours per week). Couples without children also include couples with a youngest child aged 18 years or older and, consequently, the average age of men and women is highest for couples without children. Table 1 shows that $4 \%$ of the women in couples is involuntary unemployed.

To determine disposable household income in each discrete option we use an advanced tax-benefit calculator known as MIMOSI (Romijn et al., 2008). MIMOSI is a highly advanced tax-benefit model, which calculates the budget constraints very accurately by taking into account taxes, social security contributions and group-specific subsidies and tax credits. When gross household income drops below the social assistance level we assume that the household receives a supplement that puts them at the social assistance level.

\footnotetext{
${ }^{15}$ If we exclude discouraged workers, the share of involuntary unemployment falls from $4.5 \%$ to $3.6 \%$ over the period 2006-2009.

${ }^{16}$ By contrast, Bargain et al. (2010) use the international definition whether an individual actively searched for the past four weeks and is ready to take up a job within the next two weeks. In their survey, the share of involuntary unemployment equals $6 \%$ for individuals living in couples, $10 \%$ for single men and $11 \%$ for single women.

${ }^{17}$ We use a subsample of $40 \%$ for couples without children and $20 \%$ for couples with children.
} 
Table 1: Descriptive statistics

\begin{tabular}{|c|c|c|c|c|c|c|}
\hline & \multirow[t]{2}{*}{ Singles } & \multirow[t]{2}{*}{ Single parents } & \multicolumn{2}{|c|}{ Couples without children } & \multicolumn{2}{|c|}{ Couples with children } \\
\hline & & & Men & Women & Men & Women \\
\hline \multirow[t]{2}{*}{ Age } & 41.0 & 41.6 & 47.0 & 45.4 & 42.3 & 39.8 \\
\hline & $(11.5)$ & $(7.5)$ & (11.4) & (11.5) & $(6.9)$ & (6.6) \\
\hline \multirow[t]{2}{*}{ Hourly wage } & 16.3 & 16.0 & 20.3 & 15.2 & 21.2 & 15.9 \\
\hline & $(7.7)$ & $(7.8)$ & $(10.0)$ & (6.3) & $(11.1)$ & $(7.1)$ \\
\hline \multirow[t]{2}{*}{ Hours worked per week } & 35.6 & 29.6 & 38.2 & 28.2 & 38.6 & 22.8 \\
\hline & $(8.1)$ & $(9.1)$ & $(6.0)$ & $(10.1)$ & (6.0) & $(8.7)$ \\
\hline \multicolumn{7}{|l|}{ Gender } \\
\hline Male & 0.57 & 0.11 & 1.00 & 0.00 & 1.00 & 0.00 \\
\hline Female & 0.43 & 0.89 & 0.00 & 1.00 & 0.00 & 1.00 \\
\hline \multicolumn{7}{|l|}{ Ethnicity } \\
\hline Native & 0.78 & 0.64 & 0.88 & 0.86 & 0.83 & 0.82 \\
\hline Western immigrant & 0.10 & 0.10 & 0.08 & 0.09 & 0.08 & 0.09 \\
\hline Non-Western immigrant & 0.12 & 0.26 & 0.04 & 0.05 & 0.09 & 0.09 \\
\hline \multicolumn{7}{|l|}{ Education } \\
\hline Lower educated & 0.26 & 0.34 & 0.25 & 0.32 & 0.22 & 0.22 \\
\hline Middle educated & 0.41 & 0.42 & 0.43 & 0.42 & 0.42 & 0.49 \\
\hline Higher educated & 0.33 & 0.24 & 0.32 & 0.27 & 0.35 & 0.30 \\
\hline \multicolumn{7}{|l|}{ Age of youngest child } \\
\hline Below 4 years & 0.00 & 0.16 & 0.00 & 0.00 & 0.36 & 0.36 \\
\hline Between 4 and 11 years & 0.00 & 0.45 & 0.00 & 0.00 & 0.39 & 0.39 \\
\hline Between 12 and 17 years & 0.00 & 0.39 & 0.00 & 0.00 & 0.25 & 0.25 \\
\hline \multicolumn{7}{|l|}{ Region } \\
\hline Urban area & 0.67 & 0.66 & 0.84 & 0.84 & 0.83 & 0.83 \\
\hline Non-urban area & 0.33 & 0.34 & 0.16 & 0.16 & 0.17 & 0.17 \\
\hline \multicolumn{7}{|l|}{ Employment status } \\
\hline Employed & 0.86 & 0.71 & 0.95 & 0.75 & 0.96 & 0.77 \\
\hline Involuntary unemployed & 0.05 & 0.08 & 0.02 & 0.04 & 0.01 & 0.04 \\
\hline Voluntary unemployed & 0.09 & 0.21 & 0.04 & 0.21 & 0.03 & 0.19 \\
\hline Observations & 21,510 & 7,440 & 8,748 & 8,748 & 6,378 & 6,378 \\
\hline
\end{tabular}




\section{Estimation results}

\subsection{Estimated parameters}

We first estimate a structural labour supply model without involuntary unemployment. Next, we extend this model by taking the possibility of involuntary unemployment into account. By using a probit regression, we estimate the probability of involuntary unemployment separately for single men, single women and men and women in couples. ${ }^{18}$ Table A.1 in the Appendix shows estimation results of involuntary unemployment. The probability of rationing is higher for individuals living in the non-Western region of the Netherlands (i.e. compared to the Western region), and for individuals living in an urban area. Immigrants, lower educated and older individuals also have a higher probability of being involuntary unemployed. Finally, the national unemployment rate also has a positive effect on the probability of rationing.

Tables A.2 and A.3 give the estimated preference parameters for singles without children and single parents, respectively. For both groups we start with the model in which rationing does not exist, without (w/o) involuntary unemployment. Next we consider the model that allows for demand side restrictions, with (w/) involuntary unemployed.

Table A. 2 shows that the coefficient for income is positive for singles without children. ${ }^{19}$ Negative marginal utility of income in the chosen option is not consistent with optimization behaviour but we do not find such a result. All interaction terms in the fixed costs specification are negative. ${ }^{20}$ Singles with a lower education and/or non-native background have higher fixed costs of work and participate less on average. The estimated standard deviation of the Halton draws for unobserved heterogeneity with respect to leisure is close to zero and not significant. Consequently, we restricted at zero in the estimation.

Table A.3 gives the estimated preference parameters for single parents. ${ }^{21}$ The marginal utility of leisure increases with age and is always positive. Single parents with younger children (0-3 and 4-11 years) have higher fixed costs of work than single parents with older children (12-17 years), which is the reference category. The estimated standard deviation of the random terms for leisure is close to zero, not significant, and therefore restricted its

\footnotetext{
${ }^{18}$ Here we do not distinguish between households with and without children. The presence of children is not significant in the regression of the probability of involuntary unemployment.

${ }^{19}$ The quadratic term of income and the interaction term of income with leisure were not significant and therefore excluded from the regression.

${ }^{20}$ As a robustness check, we also estimate a specification used by Bargain et al. (2010) that replaces the fixed costs specification with three separate part-time dummies. This hardly affected our results.

${ }^{21}$ The coefficient for the quadratic term of income is positive (and significant) which means that marginal utility of income is increasing for single parents.
} 
value at zero in the estimation.

Tables A.4 and A.5 give the estimated parameters of the utility function for couples without and with children, respectively. We do not find any couples with negative marginal utility of income in their preferred allocation. Marginal utility of leisure increases with age for men and women in couples. The constant term in the fixed costs of work for men is positive, an unexpected result. Furthermore, these fixed costs of work are lower for lower educated men. For women in couples, all the terms in the fixed costs specification have the expected negative sign. Women in couples with a lower education and/or non-Western background have higher fixed costs of work.

The parameters of the utility function change if we take involuntary unemployment into account. Here, we see two important differences. First, column (2) in Table A.2 shows that the coefficient for income is higher in the model with involuntary unemployment for singles. Compared to the first model without involuntary unemployment, the preference for income now increases in the model with involuntary unemployment. This is intuitive because the model without involuntary unemployment incorrectly assumes that all nonworking individuals do so on a voluntary basis, thereby attaching too low (high) value on income (leisure) in the utility function. For single parents, the preference for income increases as well in the model with involuntary unemployment. Second, the coefficients in the fixed costs of work specification change. The constant term for instance becomes less negative for single parents indicating that there is less disutility from work in the model with involuntary unemployment. ${ }^{22}$ For couples, we also find that the preference for income increases, and that fixed costs of work play a less important role in the utility function.

Table A.6 and A.7 show the fit of the models for all subgroups. The model with involuntary unemployment allows for a decomposition of non-participating individuals into voluntary and involuntary unemployed. We see that the model with involuntary unemployment predicts the share of involuntary unemployment in our population well.

\subsection{Elasticities}

We simulate elasticities by increasing gross wages by 10\%. Column (1) in Table 2 gives the labour supply elasticities for all subgroups in the model without involuntary unemployment. Men in couples and singles without children have a relatively low labour supply elasticity. The elasticity equals 0.063 for men in couples without children, which means labour supply increases by $0.063 \%$ as gross wages increase by $1 \%$. The participation rate

\footnotetext{
${ }^{22}$ In fact, the constant term in the fixed costs of work specification is even positive for singles without children. However for lower educated singles and/or immigrants, the total fixed costs of work are still negative.
} 
and the number of working hours per week is high for men in couples and singles without children. The labour supply elasticity is much higher for single parents (0.181), women in couples without children (0.193) and women in couples with children (0.314). This is primarily driven by differences in participation rates.

We decompose the total elasticity into the extensive margin and the intensive margin. Here, the reponse at the extensive margin is the percentage change in the participation rate whereas the intensive margin is the percentage change in hours worked of the employed. Table 2 shows that the extensive margin is more important than the intensive margin. These results are in line with previous findings (Bargain et al., 2014; Jongen et al., 2014; Meghir and Phillips, 2010).

The second model is the model with involuntary unemployment and exogenous job search. Not allowing for involuntary unemployment may result in biased estimates. A priori it is unclear how this bias affects the estimated elasticities. Bargain et al. (2010) give three important types of bias in the model without involuntary unemployment. First, we have a participation bias since we assume that all individuals are voluntary unemployed and are able to find a job as gross wages increase. In reality, part of the individuals are rationed on the labour market thereby limiting the response at the extensive margin and the labour supply elasticity. Hence, participation bias results in an upward bias of the labour supply elasticites. Second, there is a preference bias which means that involuntary unemployed individuals value leisure too much, when we consider them to be voluntary unemployed. This leads to a downward bias in labour supply elasticities in the model without involuntary unemployment. Third, there is a specification bias as we do not take demand side restrictions into account. The direction of this specification bias is not clear however. Bargain et al. (2010) find an overall upward bias of the elasticities and conclude that elasticities are lower in the standard labour supply model without involuntary unemployment. Euwals and Van Soest (1999) find similar results.

Table 2 shows that our simulated average elasticities are only slightly lower in the model with involuntary unemployment. An important explanation for this result is the relatively low share of individuals in our sample who are involuntary unemployed. The share of individuals who are involuntary unemployed is $1 \%$ for men in couples, $4 \%$ for women in couples and $7 \%$ for single men and women. Consequently, the participation bias is limited in our analysis. By contrast, the share of involuntary unemployment in the analysis by Bargain et al. (2010) is $6 \%$ for men and women living in couples, $10 \%$ for single men and $11 \%$ for single women. ${ }^{23}$

\footnotetext{
${ }^{23}$ Taking involuntary unemployment into account lowers elasticities in Bargain et al. (2010) from 0.300 to 0.152 for single men, 0.267 to 0.104 for single women, 0.207 to 0.117 for men in couples and 0.351 to
} 
Tables A.8 and A.9 give labour supply elasticities for several subgroups based on education, ethnicity and age. Lower educated individuals and individuals with a nonWestern background are relatively elastic with respect to labour supply. These differences are primarily driven by differences in participation rates. The labour supply responses differentiated by age give a mixed picture. For women in couples with children, the labour supply elasticities do not vary over age. The largest difference in labour supply elasticity is found for women in couples without children: 0.06 for women younger than 38 years but even 0.29 for older women. This is due to a cohort effect that women born in later years have a higher level of education than women born in earlier years. Consequently, the participation rate of young women without children is higher than the participation rate of older women with adult children. ${ }^{24}$ Older singles without children respond stronger to financial incentives than their younger counterparts. However, this situation is reversed for single parents.

By comparing the model with and without involuntary unemployement, we see that the differences in elasticities are statistically significant for most groups. Tables A.8 and A.9 show that excluding involuntary unemployment does result relatively large upward biased elasticities for lower educated individuals and non-Western immigrants. These groups face a high risk of being involuntary unemployed. The share of involuntary unemployment is $11 \%$ for lower educated single parents and only $3 \%$ for higher educated single parents. Ethnicity is also an important determinant here: $13 \%$ of non-Western immigrants is involuntary unemployed.

0.316 for women in couples.

${ }^{24}$ Recall that women with adult children are also included in this group. 
Table 2: Gross wage elasticities

\begin{tabular}{|c|c|c|}
\hline & $\begin{array}{l}\text { W/o invol. un. } \\
\text { (1) }\end{array}$ & $\begin{array}{l}\text { W/ invol. un. }{ }^{\mathrm{a}} \\
\text { (2) }\end{array}$ \\
\hline Men in couples without children & $\begin{array}{c}0.063 \\
(0.001)\end{array}$ & $\begin{array}{l}0.049^{* * *} \\
(0.000)\end{array}$ \\
\hline -extensive margin & $\begin{array}{c}0.058 \\
(0.000)\end{array}$ & $\begin{array}{l}0.045^{* * *} \\
(0.000)\end{array}$ \\
\hline -intensive margin & $\begin{array}{c}0.004 \\
(0.000)\end{array}$ & $\begin{array}{c}0.004 \\
(0.000)\end{array}$ \\
\hline Women in couples without children & $\begin{array}{c}0.193 \\
(0.001)\end{array}$ & $\begin{array}{l}0.184^{* * *} \\
(0.001)\end{array}$ \\
\hline -extensive margin & $\begin{array}{c}0.143 \\
(0.001)\end{array}$ & $\begin{array}{l}0.133^{* * *} \\
(0.001)\end{array}$ \\
\hline -intensive margin & $\begin{array}{c}0.049 \\
(0.000)\end{array}$ & $\begin{array}{l}0.051^{* * *} \\
(0.000)\end{array}$ \\
\hline Men in couples with children & $\begin{array}{c}0.068 \\
(0.001)\end{array}$ & $\begin{array}{l}0.054^{* * *} \\
(0.001)\end{array}$ \\
\hline -extensive margin & $\begin{array}{c}0.055 \\
(0.000)\end{array}$ & $\begin{array}{l}0.042^{* * *} \\
(0.000)\end{array}$ \\
\hline -intensive margin & $\begin{array}{c}0.012 \\
(0.000)\end{array}$ & $\begin{array}{c}0.012 \\
(0.000)\end{array}$ \\
\hline Women in couples with children & $\begin{array}{c}0.314 \\
(0.002)\end{array}$ & $\begin{array}{l}0.283^{* * *} \\
(0.002)\end{array}$ \\
\hline -extensive margin & $\begin{array}{c}0.209 \\
(0.002)\end{array}$ & $\begin{array}{l}0.176^{* * *} \\
(0.001)\end{array}$ \\
\hline -intensive margin & $\begin{array}{c}0.102 \\
(0.001)\end{array}$ & $\begin{array}{l}0.105^{* * *} \\
(0.001)\end{array}$ \\
\hline Singles without children & $\begin{array}{c}0.043 \\
(0.001)\end{array}$ & $\begin{array}{l}0.049^{* * *} \\
(0.001)\end{array}$ \\
\hline -extensive margin & $\begin{array}{c}0.038 \\
(0.001)\end{array}$ & $\begin{array}{l}0.041^{* * *} \\
(0.001)\end{array}$ \\
\hline -intensive margin & $\begin{array}{c}0.005 \\
(0.000)\end{array}$ & $\begin{array}{l}0.008^{* * *} \\
(0.000)\end{array}$ \\
\hline Single parents & $\begin{array}{c}0.181 \\
(0.002)\end{array}$ & $\begin{array}{l}0.148^{* * *} \\
(0.002)\end{array}$ \\
\hline -extensive margin & $\begin{array}{c}0.136 \\
(0.002)\end{array}$ & $\begin{array}{l}0.103^{* * *} \\
(0.001)\end{array}$ \\
\hline -intensive margin & $\begin{array}{c}0.044 \\
(0.001)\end{array}$ & $\begin{array}{c}0.044 \\
(0.001)\end{array}$ \\
\hline
\end{tabular}

${ }^{a}$ Based on the model with exogenous job search.

b Bootstrapped standard errors based on 200 draws.

c T-test: statistically different from the model without involuntary unemployment $\left({ }^{* * *} \mathrm{p}<0.01,{ }^{* *} \mathrm{p}<0.05,{ }^{*} \mathrm{p}<0.10\right)$. 


\section{$5 \quad$ Policy simulations}

The previous section showed that the average gross labour supply elasticities are similar in the model with and without involuntary unemployment. However, it is still possible that certain policy simulations, because of the targeting of the policy reform and magnitude of the impulse, lead to different labour supply responses across these models. We simulate four different reforms and compare results of both models.

The first scenario is a reduction of welfare benefits (in Dutch: Bijstand) with 500 million euro, which corresponds to a reduction of the net social welfare benefit by 14 percent. It is a means tested benefit for households whose income is below the minimum amount to meet their living expenses, the so-called social minimum. People receive welfare benefits if they are long-term unemployed and are not entitled to unemployement benefits. A reduction of welfare benefits leads to a substantial increase in labour supply as labour supply responds strongly to stimuli that engage directly in the choice between working and not working (extensive margin). Lowering welfare benefits particularly affects single parents, who are relatively elastic with respect to labour supply, and represent a large share of the population with welfare benefits. Approximately $27 \%$ of single parents in our sample receive welfare benefits. Column (1) in Table 3 shows that single parents increase their labour supply by $2.82 \%$. The share of singles, without children, receiving welfare benefits is much lower (15\%) and they increase their labour supply by $0.74 \%$. The labour supply effects for couples are limited. This is intuitively appealing since the share of couples with social welfare is relatively low. ${ }^{25}$ The lower part of Table 3 shows the aggregated effect for the whole population. Overall, labour supply increases by $0.53 \%$ which boils down to 37,000 FTEs.

Taking demand side restrictions into account, the constrained model finds a slightly lower effect: the overall effect falls from $0.53 \%$ to $0.46 \%$, or from 37,000 FTEs to 33,000 FTEs. However, the difference between both models is much more prominent for single parents, as expected. The labour supply response falls from $2.82 \%$ in the model without involuntary unemployment to $2.25 \%$ in the model with involuntary unemployment. Single parents respond relatively strong to a reduction of welfare benefits, and in addition, they face a high risk at being involuntary unemployed.

The second scenario is a reduction in the income dependent child benefit (in Dutch: Kindgebonden budget (KGB)), again for 500 million euro. The KGB is a subsidy for households with a youngest child up to 18 years of age. Households receive an amount per child. ${ }^{26}$ The subsidy depends upon household income and is phased out from 19,463 euro

\footnotetext{
${ }^{25}$ Only $2 \%$ and $3 \%$ of the couples without and with children in our sample receive welfare benefits.

${ }^{26}$ In 2015, the maximum amount per child is: 1,032 euro for the first child, 791 euro for the second
} 
at a rate of $6.75 \%$. Non-working households therefore usually receive a higher subsidy than households where both (or at least one of the) partners work. Moreover, the KGB increases the effective marginal tax burden for working people with low incomes. Column (2) gives the labour supply effects of the reduction in the KGB. This reform stimulates parents to start working (extensive margin) and to work more hours per week (intensive margin). Men and women in couples with children and single parents increase their labour supply. For all subgroups with children, we find lower effects in the model with involuntary unemployment. Overall, the total effect falls from $0.30 \%$, or 21,000 FTEs, to $0.25 \%$, or 17,000 FTEs when we acount for involuntary unemployment.

The third scenario is an increase in the general in-work tax credit for all workers (in Dutch: Arbeidskorting (AK)) for 500 million euro. The AK rises up to a personal labour income of 19,463 and the maximum AK equals 2,220 euro in 2015. The AK remains constant between an income of 19,463 and 49,769 euro. From an income of 49,769 euro the $\mathrm{AK}$ is phased out with a percentage of $4 \%$ until the minimum $\mathrm{AK}$ of 184 euro is reached at an income of 100,669 euro. We increase the maximum amount of the AK by 130 euro. Column (3) of Table 3 shows that increasing the AK is relatively ineffective in stimulating labour supply. Overall, labour supply increases $0.05 \%$ (4,000 FTEs). The effect of the AK is limited because a large part of the budget goes to primary earners, mostly men, who are relatively inelastic with respect to their labour supply. The model with involuntary unemployment produces slightly lower labour supply effects: $0.04 \%$, or 3,000 FTEs.

The last scenario is an increase in the income dependent combination credit (in Dutch: Inkomensafhankelijke Combinatiekorting (ICK)) for working parents with a youngest child under 12 years. The impuls is 500 million euro. The ICK is a tax credit for working single parents and secondary earners. The phase-in of the ICK starts at a personal income of 4,857 euro and rises with income at a rate of $4 \%$ in 2015 . The maximum amount of the ICK, 1,109 euro in 2015, is reached at income of 32,832 euro. We simulate an increase in the ICK by 870 euro. The ICK is more effective in stimulating labour supply than the AK: labour supply now increases $0.23 \%$ or 16,000 FTEs. The ICK targets at single parents and seconday earners, mostly women, who respond more strongly to financial incentives. Primary earners do not receive the ICK. By taking involuntary unemployment into account, the overall effect falls from $0.23 \%$ to $0.21 \%$, or from 16,000 FTEs to 15,000 FTEs.

child, 183 euro for the third child and 106 euro for the fourth, fifth and sixth child. 
Table 3: Results policy simulations

\begin{tabular}{|c|c|c|c|c|}
\hline & \multirow{2}{*}{$\begin{array}{c}\text { Welfare benefits }^{\mathrm{a}} \\
\text { (1) }\end{array}$} & \multirow{2}{*}{$\begin{array}{l}\text { Child benefits }^{\text {b }} \\
\text { (2) }\end{array}$} & \multicolumn{2}{|c|}{ In-work tax credit } \\
\hline & & & $\begin{array}{c}\text { All workers }{ }^{\mathrm{c}} \\
\text { (3) }\end{array}$ & $\begin{array}{c}\text { Working parents }{ }^{\mathrm{d}} \\
(4)\end{array}$ \\
\hline \multicolumn{5}{|c|}{ Percentage changes } \\
\hline \multicolumn{5}{|c|}{ Men, couples without children } \\
\hline W/o invol. un. & 0.50 & 0.00 & -0.01 & 0.00 \\
\hline W invol. un. ${ }^{*}$ & 0.41 & 0.00 & -0.01 & 0.00 \\
\hline \multicolumn{5}{|c|}{ Women, couples without children } \\
\hline W/o invol. un. & 0.25 & 0.00 & 0.13 & 0.00 \\
\hline W invol. un. & 0.22 & 0.00 & 0.12 & 0.00 \\
\hline \multicolumn{5}{|c|}{ Men, couples with children } \\
\hline W/o invol. un. & 0.34 & 0.57 & 0.00 & 0.00 \\
\hline W invol. un. & 0.21 & 0.45 & -0.01 & 0.00 \\
\hline \multicolumn{5}{|c|}{ Women, couples with children } \\
\hline W/o invol. un. & 0.22 & 0.82 & 0.18 & 1.27 \\
\hline W invol. un. & 0.14 & 0.72 & 0.16 & 1.18 \\
\hline \multicolumn{5}{|c|}{ Singles without children } \\
\hline W/o invol. un. & 0.74 & 0.00 & 0.03 & 0.00 \\
\hline W invol. un. & 0.83 & 0.00 & 0.03 & 0.00 \\
\hline \multicolumn{5}{|l|}{ Single parents } \\
\hline W/o invol. un. & 2.82 & 0.58 & 0.13 & 0.78 \\
\hline W invol. un. & 2.25 & 0.51 & 0.10 & 0.63 \\
\hline \multicolumn{5}{|c|}{ Overall hours worked per week } \\
\hline W/o invol. un. & 0.53 & 0.30 & 0.05 & 0.23 \\
\hline \multirow[t]{2}{*}{ W invol. un. } & 0.46 & 0.25 & 0.04 & 0.21 \\
\hline & \multicolumn{3}{|c|}{ Fulltime Equivalents } & \\
\hline W/o invol. un. & 37,000 & 21,000 & 4,000 & 16,000 \\
\hline W invol. un. & 33,000 & 17,000 & 3,000 & 15,000 \\
\hline
\end{tabular}

* Based on the model with exogenous job search.

${ }^{a}$ Reduction in net welfare benefits by $14 \%$.

${ }^{\mathrm{b}}$ Reduction in child benefits (KGB) by $55 \%$. The KGB is an income dependent subsidy for households with a child up to 18 years of age. The subsidy depends upon household income and is phased out from 19,463 euro at a rate of $6.75 \%$ in 2015 .

${ }^{c}$ An increase in the maximum amount of the general tax credit for all workers (AK) by 130 euro. The AK rises up to a personal income of 19,463 and the maximum AK equals 2,220 euro in 2015.

${ }^{d}$ An increase in the maximum amount of the combination tax credit (ICK) by 870 euro. The ICK is a tax credit for working single parents and secondary earners with a youngest child up to 12 years of age. The phase-in of the ICK starts at a personal income of 4,857 euro and rises with income at a rate of $4 \%$ until the maximum ICK of 1,109 euro is reached in 2015 . 


\section{Extension: job search endogenous}

For singles without children and single parents we extend the model with involuntary unemployment by allowing for endogenous job search. We estimate the model only for singles and single parents. This is the group for which the share of involuntary unemployment is relatively high. In addition, the endogenous search model is complex and the numerical challenge is much lower for singles compared to couples, as singles have less alternatives in their discrete choice set.

Column (3) in Table A.2 and A.3 give the estimated parameters for our third en last model, with endogenous job search behaviour. Here, the model includes an additional variable: search costs. We estimate search costs as a constant term and we find that the coefficient is negative and significant for all subgroups. Hence, search costs lower utility, as expected. Moving from the model with involuntary unemployment and exogenous job search, to the model with endogenous job search, we see that the constant term of the fixed costs specification increases further. Apparently, our search costs take up part of the fixed costs of work. For individuals with a high risk of unemployment, such as single parents with a low education and/or non-Western background, the total fixed costs of work are still negative. Table A.6 illustrates that the fit of the model, with endogenous job search, is similar to the previous model. For single parents, the model with endogenous job search gives a better prediction of the share of individuals who are involuntary unemployed (7\%) than the model with exogenous job search (5\%).

Column (3) in Table 4 gives the elasticities for the model with endogenous job search for singles without children and single parents. By making job search endogenous, the labour supply elasticities become slightly lower. For singles without children, the average labour supply elasticity falls from 0.049 to 0.046 , whereas the average labour supply elasticity falls from 0.148 to 0.136 for single parents. There are two opposing effects at work here. First, a higher job search probability exerts an upward pressure on labour supply elasticities (see equation 14), but this effect is limited. Singles without children increase their search effort by $0.038 \%$ if wages increase by 1 percent. For single parents, the increase in the job search probability is higher: $0.085 \%$. By making job search endogenous, the model predicts that individuals search more as wages increase. Second, preferences for income, leisure and the fixed costs specification change. Search costs now account for part of the costs in the fixed costs specification.

Finally, we compare the three models on the basis of the reform with the largest behavioural responses: reducing welfare benefits. Table 5 gives the labour supply effects for all subgroups and illustrates that there are large differences between subgroups. Lower 
educated individuals and immigrants receive welfare benefits relatively frequent. In 2009, $47 \%$ of all individuals receiving welfare benefits are non-Western immigrants whereas their share in the total Dutch population is only $11 \% .{ }^{27}$ By lowering welfare benefits by $14 \%$, lower educated single parents increase labour supply by $5.95 \%$ in the model without involuntary unemployment. However, the share of involuntary unemployment is also relatively high among lower educated single parents. Consequently, the bias of neglecting involuntary unemployment is relatively high for lower educated single parents. Column (2) shows that taking involuntary unemployment into account lowers the labour supply response of lower educated single parents to $4.84 \%$.

By making job search endogenous, the total labour supply effect falls from $0.83 \%$ to $0.80 \%$ for singles without children and from $2.25 \%$ to $2.07 \%$ for single parents. Again, the differences are relatively large for subgroups with a high risk of being involuntary unemployed, such as lower educated singles and immigrants. Column (3) gives the labour supply effects in the model with endogenous job search, where the increase in job search probability is between parentheses. Job search activity increases strongly for single parents with a lower education (3.27\%), non-Western background $(3.62 \%)$ and younger than 38 years $(3.72 \%)$. Here we see that lowering welfare benefits results in individuals shifting from the group of non-searchers to searchers. However, as for the elasticities, labour supply responses are lowest in the model with endogenous job search for all subgroups.

\footnotetext{
${ }^{27}$ Statistics Netherlands, available online at http://statline.cbs.nl.
} 
Table 4: Elasticities singles and single parents

\begin{tabular}{lccc}
\hline & W/o invol. un. & \multicolumn{2}{c}{ W/ invol. un. } \\
& & job search exogenous & job search endogenous \\
\hline Singles without children & 0.043 & $0.049^{* * *}$ & 0.046 \\
-extensive margin & $(0.001)$ & $(0.001)$ & $(0.002)$ \\
& 0.038 & $0.041^{* * *}$ & 0.039 \\
-intensive margin & $(0.001)$ & $(0.001)$ & $(0.002)$ \\
& 0.005 & $0.008^{* * *}$ & $0.007^{* * *}$ \\
Single parents & $(0.000)$ & $(0.000)$ & $(0.000)$ \\
& & & \\
-extensive margin & 0.181 & $0.148^{* * *}$ & $0.136^{* * *}$ \\
-intensive margin & $(0.002)$ & $(0.002)$ & $(0.003)$ \\
& 0.136 & $0.103^{* * *}$ & $0.095^{* * *}$ \\
& $(0.002)$ & $(0.001)$ & $(0.002)$ \\
& 0.044 & 0.044 & $0.041^{* * *}$ \\
\hline
\end{tabular}

${ }^{\mathrm{a}}$ Bootstrapped standard errors based on 200 draws.

b T-test: statistically different from the model without involuntary unemployment $\left({ }^{* * *} \mathrm{p}<0.01\right.$, ** $\mathrm{p}<0.05, * \mathrm{p}<0.10)$. 
Table 5: Lowering welfare benefits ${ }^{\mathrm{a}}$

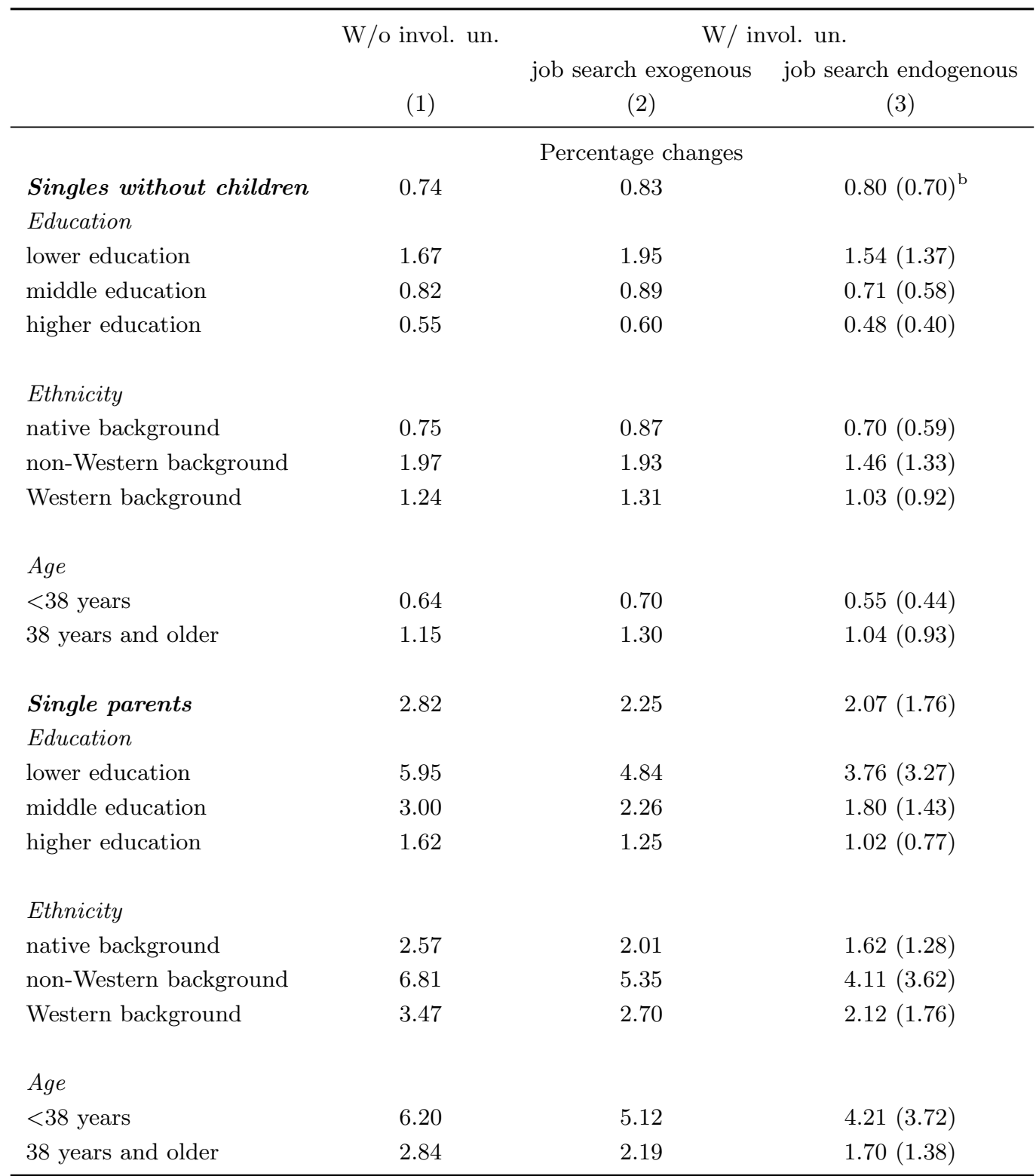

${ }^{a}$ Reduction in net welfare benefits by $14 \%$.

$\mathrm{b}$ The increase in job search between parentheses. 


\section{Discussion}

Structural models for labour supply typically assume that individuals freely choose their preferred alternative from a fixed discrete choice set. In reality, demand side restrictions may limit these discrete choice sets. We use information from the Labour Market Panel of Statistics Netherlands for the period 2006-2009 to estimate a structural model of labour supply with involuntary unemployment. We find that taking into account involuntary unemployment makes little difference to the average labour supply elasticities. Only for certain subgroups, with a high risk at being involuntary unemployed, we find a relatively large upward bias in elasticities in the model without involuntary unemployment. A simulation of tax-benefit reforms confirms that taking demand side restrictions into account results in slightly lower aggregated effects.

Our data contains both years when the economy was doing very well, 2006-2007, and the first years of the Great Recession, 2008-2009. But this may not be a bad approximation for the structural situation on the Dutch labour market once the Great Recession is over. This study provides empirical evidence that standard labour supply models, in which rationing does not exist, give a good prediction of the effects of tax reforms as long as the level of unemployment in a country is relatively low.

\section{References}

Aaberge, R. and Colombino, U. (2009). Evaluating alternative representations of the choice sets in models of labor supply. Journal of Economic Surveys, 21(3):586-612.

Aaberge, R., Colombino, U., and Strom, S. (1999). Labour supply in Italy: an empirical analysis of joint household decisions, with taxes and quantity constraints. Journal of Applied Econometrics, 14(4):403-422.

Bargain, O., Caliendo, M., Haan, P., and Orsini, K. (2010). 'Making work pay' in a rationed labour market. Journal of Population Economics, 23(1):323-351.

Bargain, O., Orsini, K., and Peichl, A. (2014). Comparing labor supply elasticities in Europe and the United States: new results. Journal of Human Resources, 49(3):723838.

Blundell, R., Ham, J., and Meghir, C. (1987). Unemployment and female labour supply. The Economic Journal, 97:44-64. 
Blundell, R. and Shephard, A. (2012). Employment, hours of work and the optimal taxation of low income families. Review of Economic Studies, 79(2):481-510.

Cragg, J. (1971). Some statistical models for limited dependent variables with applications to the demand for durable goods. Econometrica, 39:829-844.

Creedy, J. and Kalb, G. (2005). Discrete hours labour supply modelling: specification, estimation and simulation. Journal of Economic Surveys, 19(5):697-738.

Euwals, R. and Van Soest, A. (1999). Desired and actual labour supply of married men and women in the netherlands. Labour Economics, 6:95-118.

Hogan, V. (2004). The welfare cost of taxation in a labor market with unemployment and non-participation. Labour Economics, 11:395-413.

Jongen, E., Boer, H.-W., and Dekker, P. (2014). Micsim: A behavioural microsimulation model for the analysis of tax-benefit reform in the netherlands. mimeo, CPB Netherlands Bureau for Economic Policy Analysis, The Hague.

Keane, M. and Moffitt, R. (1998). A structural model of multiple welfare program participation and labor supply. International Economic Review, 39(3):553-589.

Krueger, A., Cramer, J., and Cho, D. (2014). Are the long-term unempoyed on the margins of the labor market? Brookings Papers on Economic Research, pages 229-280.

Laroque, G. and Salanie, B. (2002). Labour market institutions and employment in france. Journal of Applied Econometrics, 17:25-48.

McFadden, D. (1974). Conditional logit analysis of qualitative choice behavior. In Zarembka, P., editor, Frontiers in Econometrics. Academic.

Meghir, C. and Phillips, D. (2010). Labour supply and taxes. In Mirrlees, J. A., Adam, S., Besley, T. J., Blundell, R., Bond, S., Chote, R., Gammie, M., Johnson, P., Myles, G. D., and Poterba, J. M., editors, The Mirrlees Review - Dimensions of Tax Design, chapter 3, pages 202-274. Oxford University Press, Oxford.

Moulton, B. (1990). An illustration of a pitfall in estimating the effects of aggregate variables on micro units. Review of Economic Statistics, 72(2):334-338.

OECD (2013). OECD Labour Force Statistics. Paris.

OECD (2014). OECD Employment Outlook. Paris. 
Pissarides, C. (2000). Equilibrium Unemployment Theory. The MIT Press, Cambridge, 2nd edition.

Romijn, G., Goes, J., Dekker, P., Gielen, M., and van Es, F. (2008). MIMOSI: Microsimulatiemodel voor belastingen, sociale zekerheid, loonkosten en koopkracht. CPB Document 161, The Hague.

Statistics Netherlands (2009). EBB: methoden en definities. http://www.cbs.nl/NR/rdonlyres/150506F0-38F8-4AAD-B252-F91C952DFDF6 /0/2010ebbmethodenendefinities2009a.pdf.

Statistics Netherlands (2012). Documentatierapport Arbeidsmarktpanel 1999-2009V1. Voorburg.

Van Soest, A. (1995). Structural models of family labor supply: a discrete choice approach. Journal of Human Resources, 30(1):63-88. 
Appendix 


\section{A Probabilities couples model with involuntary unemploy- ment}

For couples we have nine possible states on the labour market.

1) Man and woman voluntary unemployed:

$$
P_{i}^{V O L_{m}, V O L_{f}}=\frac{\exp \left(U_{i 1}\right)}{\sum_{j=1}^{J} \exp \left(U_{i j}\right)},
$$

2) Man involuntary unemployed and woman voluntary unemployed

$$
P_{i}^{I N V O L_{m}, V O L_{f}}=\Phi_{m}(\beta \boldsymbol{X}) \sum_{k \in\left(h_{m}>0, h_{f}=0\right)}^{J} \frac{\exp \left(U_{i k}\right)}{\sum_{j=1}^{J} \exp \left(U_{i j}\right)},
$$

3) Man voluntary unemployed and woman involuntary unemployed

$$
P_{i}^{V O L_{m}, I N V O L_{f}}=\Phi_{f}(\beta \boldsymbol{X}) \sum_{k \in\left(h_{m}=0, h_{f}>0\right)}^{J} \frac{\exp \left(U_{i k}\right)}{\sum_{j=1}^{J} \exp \left(U_{i j}\right)},
$$

4) Man and woman involuntary unemployed:

$$
P_{i}^{I N V O L_{m}, I N V O L_{f}}=\Phi_{m}(\beta \boldsymbol{X}) \sum_{k \in\left(h_{m}>0, h_{f}>0\right)}^{J} \frac{\exp \left(U_{i k}\right)}{\sum_{j=1}^{J} \exp \left(U_{i j}\right)},
$$

5) Man employed and woman voluntary unemployed:

$$
P_{i, k \in\left(h_{m}>0, h_{f}=0\right)}^{E M P_{m}, V O L_{f}}=\left(1-\Phi_{m}(\beta \boldsymbol{X})\right) \frac{\exp \left(U_{i k}\right)}{\sum_{j=1}^{J} \exp \left(U_{i j}\right)} .
$$

6) Man voluntary unemployed and woman employed:

$$
P_{i, k \in\left(h_{m}=0, h_{f}>0\right)}^{V O L_{m}, E M P_{f}}=\left(1-\Phi_{f}(\beta \boldsymbol{X})\right) \frac{\exp \left(U_{i k}\right)}{\sum_{j=1}^{J} \exp \left(U_{i j}\right)} .
$$

7) Man employed and woman involuntary unemployed:

$$
P_{i, k \in h_{m}>0}^{E M P_{m}, I N V O L_{f}}=\left(1-\Phi_{m}(\beta \boldsymbol{X})\right) \Phi_{f}(\beta \boldsymbol{X}) \sum_{k \in h_{f}>0}^{J} \frac{\exp \left(U_{i k}\right)}{\sum_{j=1}^{J} \exp \left(U_{i j}\right)} .
$$

8) Man involuntary unemployed and woman employed:

$$
P_{i, k \in h_{f}>0}^{I N V O L_{m}, E M P_{f}}=\Phi_{m}(\beta \boldsymbol{X})\left(1-\Phi_{f}(\beta \boldsymbol{X})\right) \sum_{k \in h_{m}>0}^{J} \frac{\exp \left(U_{i k}\right)}{\sum_{j=1}^{J} \exp \left(U_{i j}\right)} .
$$

9) Man and woman employed:

$$
P_{i, k \in\left(h_{m}>0, h_{f}>0\right)}^{E M P_{m}, E M P_{f}}=\left(1-\Phi_{m}(\beta \boldsymbol{X})\right)\left(1-\Phi_{f}(\beta \boldsymbol{X})\right) \frac{\exp \left(U_{i k}\right)}{\sum_{j=1}^{J} \exp \left(U_{i j}\right)} .
$$




\section{B Probability involuntary unemployment}

Table A.1: Estimation results involuntary unemployment

\begin{tabular}{|c|c|c|c|c|}
\hline & \multicolumn{2}{|c|}{ Singles } & \multicolumn{2}{|c|}{ Couples } \\
\hline & Men & Women & Men & Women \\
\hline \multicolumn{5}{|l|}{ Region } \\
\hline Urban area & $0.154^{* * *}$ & 0.043 & $0.059^{* *}$ & $0.058 * *$ \\
\hline North & $0.321^{* * *}$ & $0.314^{* * *}$ & $0.212^{* * *}$ & $0.254^{* * *}$ \\
\hline East & 0.004 & $0.113^{* *}$ & $0.048^{*}$ & $0.094^{* * *}$ \\
\hline South & 0.001 & 0.007 & $0.066^{* * *}$ & $0.062^{* * *}$ \\
\hline \multicolumn{5}{|l|}{ Ethnicity } \\
\hline Non-Western immigrant & $0.719^{* * *}$ & $0.541^{* * *}$ & $0.713^{* * *}$ & $0.442 * * *$ \\
\hline Western immigrant & $0.339^{* * *}$ & $0.178^{* * *}$ & $0.281^{* * *}$ & $0.203^{* * *}$ \\
\hline \multicolumn{5}{|l|}{ Education } \\
\hline Lower education & $0.437^{* * *}$ & $0.591^{* * *}$ & $0.281 * * *$ & $0.337^{* * *}$ \\
\hline Middle education & $0.193^{* * *}$ & $0.290^{* * *}$ & $0.145^{* * *}$ & $0.147^{* * *}$ \\
\hline Age $>=50$ years & 0.065 & -0.053 & $0.291 * * *$ & $0.056^{* * *}$ \\
\hline Unemployment $^{\mathrm{a}}$ & $0.140^{* * *}$ & $0.142^{* * *}$ & $0.095^{* * *}$ & $0.093^{* * *}$ \\
\hline Constant & $-2.814^{* * *}$ & $-2.803^{* * *}$ & $-2.855^{* * *}$ & $-2.500 * * *$ \\
\hline Observations & 13,897 & 16,036 & 82,060 & 78,300 \\
\hline Log likelihood & $-2,460$ & $-3,058$ & $-8,655$ & $-13,045$ \\
\hline
\end{tabular}

$* * * \mathrm{p}<0.01, * * \mathrm{p}<0.05, * \mathrm{p}<0.10$.

${ }^{a}$ Moulton (1990) corrected standard errors. 


\section{Preferences of the model}

Table A.2: Parameters utility function singles without children

\begin{tabular}{|c|c|c|c|}
\hline & \multirow{2}{*}{$\begin{array}{l}\text { w/o involuntary UE } \\
\text { (1) }\end{array}$} & \multicolumn{2}{|c|}{ w/ involuntary UE } \\
\hline & & $\begin{array}{l}\text { Job search exogenous } \\
\text { (2) }\end{array}$ & $\begin{array}{l}\text { Job search endogenous } \\
\text { (3) }\end{array}$ \\
\hline Income & $0.421^{* * *}$ & $0.685^{* * *}$ & $0.605^{* * *}$ \\
\hline Leisure & $39.020 * * *$ & $37.590 * * *$ & $37.710^{* * *}$ \\
\hline $\mathrm{X}($ age -38$) / 10$ & $1.345^{* * *}$ & $1.200 * * *$ & $1.131^{* * *}$ \\
\hline $\mathrm{X}(\text { age }-38)^{2} / 100$ & $1.044^{* * *}$ & $1.312^{* * *}$ & $1.196^{* * *}$ \\
\hline Leisure $^{2}$ & $371.300^{* * *}$ & $360.800^{* * *}$ & $362.000^{* * *}$ \\
\hline Leisure $^{3}$ & $730.200^{* * *}$ & $712.100 * * *$ & $714.700^{* * *}$ \\
\hline Fixed costs of work & $-0.090 * * *$ & $0.195^{* * *}$ & $2.949 * * *$ \\
\hline X 1 (low education) & $-1.041 * * *$ & $-0.921 * * *$ & $-0.832^{* * *}$ \\
\hline X 1(middle education) & $-0.325 * * *$ & $-0.200 * * *$ & $-0.168 * * *$ \\
\hline X 1 (non-Western immigrant) & $-1.407 * * *$ & $-1.056 * * *$ & $-0.831 * * *$ \\
\hline X 1(Western immigrant) & $-0.703 * * *$ & $-0.523^{* * *}$ & $-0.454^{* * *}$ \\
\hline Search $\operatorname{costs}^{\mathrm{a}}$ & & & $-1.423^{* * *}$ \\
\hline Observations & 21,510 & 21,510 & 21,510 \\
\hline
\end{tabular}

*** $\mathrm{p}<0.01,{ }^{* *} \mathrm{p}<0.05,{ }^{*} \mathrm{p}<0.10$. 
Table A.3: Parameters utility function single parents

\begin{tabular}{|c|c|c|c|}
\hline & \multirow{2}{*}{$\begin{array}{c}\text { w/o involuntary UE } \\
\text { (1) }\end{array}$} & \multicolumn{2}{|c|}{$\mathrm{w} /$ involuntary UE } \\
\hline & & $\begin{array}{l}\text { Job search exogenous } \\
\text { (2) }\end{array}$ & $\begin{array}{l}\text { Job search endogenous } \\
\text { (3) }\end{array}$ \\
\hline Income & $-1.049 * * *$ & $-1.275^{* * *}$ & $-2.148 * * *$ \\
\hline Income $^{2}$ & $1.103^{* * *}$ & $1.230^{* * *}$ & $1.620^{* * *}$ \\
\hline Leisure & $-13.010 * * *$ & $-17.300^{* * *}$ & $-19.220^{* * *}$ \\
\hline $\mathrm{X}($ age -38$) / 10$ & $-1.869 * * *$ & $-1.570 * * *$ & $-1.873^{* * *}$ \\
\hline $\mathrm{X}(\text { age }-38)^{2} / 100$ & $0.615^{* * *}$ & $0.444^{* * *}$ & $0.553^{* * *}$ \\
\hline Leisure $^{2}$ & $87.410^{* * *}$ & $69.510^{* * *}$ & $75.440 * * *$ \\
\hline Leisure $^{3}$ & $333.700^{* * *}$ & $305.200 * * *$ & $311.600 * * *$ \\
\hline Fixed costs of work & $-1.837 * * *$ & $-1.760 * * *$ & $0.428^{* * *}$ \\
\hline X 1 (low education) & $-1.376 * * *$ & $-1.281 * * *$ & $-1.358 * * *$ \\
\hline X 1(middle education) & $-0.307 * * *$ & $-0.217 * * *$ & $-0.195^{* * *}$ \\
\hline X 1(non-Western immigrant) & $-1.176 * * *$ & $-0.998 * * *$ & $-1.029 * * *$ \\
\hline X 1(Western immigrant) & $-0.565^{* * *}$ & $-0.522 * * *$ & $-0.532 * * *$ \\
\hline X 1 (youngest child $0-3$ yrs) & $-0.233^{* * *}$ & $-0.339 * * *$ & $-0.400 * * *$ \\
\hline X 1(youngest child 4-11 yrs) & $-0.161^{* * *}$ & $-0.186^{* * *}$ & $-0.218^{* * *}$ \\
\hline Income*leisure & $4.236^{* * *}$ & $4.740^{* * *}$ & $6.895^{* * *}$ \\
\hline Search $\operatorname{costs}^{\mathrm{a}}$ & & & -0.567 \\
\hline Observations & 7,440 & 7,440 & 7,440 \\
\hline
\end{tabular}

*** $\mathrm{p}<0.01, * * \mathrm{p}<0.05, * \mathrm{p}<0.10$.

${ }^{\text {a }}$ Interaction terms with education, ethnicity and age are not significant. 
Table A.4: Parameters utility function couples without children

w/o involuntary UE w/ involuntary UE

(1)

(2)

\begin{tabular}{|c|c|c|}
\hline Income & $2.938^{* * *}$ & $3.606^{* * *}$ \\
\hline Income $^{2}$ & $0.067 * * *$ & $-0.049 *$ \\
\hline Leisure man & $74.690^{* * *}$ & $77.430 * * *$ \\
\hline $\mathrm{X}($ age $\operatorname{man}-38) / 10$ & $1.723^{* * *}$ & $1.495 * * *$ \\
\hline $\mathrm{X}(\text { age } \operatorname{man}-38)^{2} / 100$ & $0.956^{* * *}$ & $1.056^{* * *}$ \\
\hline Leisure $\operatorname{man}^{2}$ & $584.200^{* * *}$ & $592.900 * * *$ \\
\hline Leisure $\operatorname{man}^{3}$ & $1017.000^{* * *}$ & $1032.000^{* * *}$ \\
\hline Leisure woman & $6.546^{* * *}$ & $9.171^{* * *}$ \\
\hline $\mathrm{X}($ age woman -38$) / 10$ & $5.446^{* * *}$ & $5.783^{* * *}$ \\
\hline $\mathrm{X}(\text { age woman }-38)^{2} / 100$ & $0.795^{* * *}$ & $0.731^{* * *}$ \\
\hline Leisure woman $^{2}$ & $133.300^{* * *}$ & $134.300^{* * *}$ \\
\hline Leisure woman ${ }^{3}$ & $424.700^{* * *}$ & $429.700 * * *$ \\
\hline Fixed costs of work man & $0.735^{* * *}$ & $0.892^{* * *}$ \\
\hline X 1(low educated man) & $0.097 * * *$ & $0.390 * * *$ \\
\hline X 1(middle education man) & $0.347^{* * *}$ & $0.657^{* * *}$ \\
\hline X 1(non-Western immigrant man) & $-1.693^{* * *}$ & $-1.686 * * *$ \\
\hline X 1(Western immigrant man) & $-0.763^{* * *}$ & $-0.681^{* * *}$ \\
\hline Fixed costs of work woman & $-0.731 * * *$ & $-0.500 * * *$ \\
\hline X 1(low educated woman) & $-1.084 * * *$ & $-1.060 * * *$ \\
\hline X 1(middle education woman) & $-0.374 * * *$ & $-0.422 * * *$ \\
\hline X 1(non-Western immigrant woman) & $-1.235^{* * *}$ & $-0.968 * * *$ \\
\hline X 1(Western immigrant woman) & $-0.316^{* * *}$ & $-0.254^{* * *}$ \\
\hline Income $\mathrm{X}$ leisure man & $4.095^{* * *}$ & $4.152^{* * *}$ \\
\hline Income $\mathrm{X}$ leisure woman & $-2.865 * * *$ & $-3.508 * * *$ \\
\hline Leisure man X leisure woman & $2.224^{* * *}$ & $6.815^{* * *}$ \\
\hline Observations & 8,748 & 8,748 \\
\hline
\end{tabular}

*** $\mathrm{p}<0.01,{ }^{* *} \mathrm{p}<0.05,{ }^{*} \mathrm{p}<0.10$. 
Table A.5: Parameters utility function couples with children w/o involuntary UE w/ involuntary UE

(1)

(2)

Income

Income $^{2}$

Leisure man

$\mathrm{X}$ (age man -38)/10

$\mathrm{X}(\text { age man }-38)^{2} / 100$

Leisure $\operatorname{man}^{2}$

Leisure $\operatorname{man}^{3}$

Leisure woman

$\mathrm{X}$ (age woman -38)/10

$\mathrm{X}(\text { age woman }-38)^{2} / 100$

Leisure woman $^{2}$

Leisure woman $^{3}$

Fixed costs of work man

X 1(low educated man)

$\mathrm{X}$ 1(middle education man)

$\mathrm{X}$ 1(non-Western immigrant man)

X 1(Western immigrant man)

$\mathrm{X}$ 1(youngest child 0-3 yrs)

$\mathrm{X} 1$ (youngest child 4-11 yrs)

Fixed costs of work woman

X 1(low educated woman)

$\mathrm{X}$ 1(middle education woman)

X 1(non-Western immigrant woman)

$\mathrm{X}$ 1(Western immigrant woman)

$\mathrm{X} 1$ (youngest child 0-3 yrs)

$\mathrm{X} 1$ (youngest child 4-11 yrs)

Income X leisure man

Income $\mathrm{X}$ leisure woman

Leisure man X leisure woman

\section{$1.042^{* * *}$}

$1.438^{*}$

$69.800 * * *$

$1.281^{* * *}$

$1.090 * * *$

$581.000 * * *$

$1004.000^{* * *}$

$-37.230 * * *$

$0.381 * * *$

$0.407^{* * *}$

$-170.700^{* * *}$

$-133.100 * * *$

$\begin{array}{lc}0.584^{* * *} & 0.611^{* * *} \\ -0.012 & 0.166^{* * *} \\ 0.630^{* * *} & 0.832^{* * *} \\ -1.654^{* * *} & -1.319^{* * *} \\ -0.927^{* * *} & -0.678^{* * *} \\ -0.201^{* * *} & -0.253^{* * *} \\ -0.088^{* * *} & 0.026\end{array}$

$-2.090 * * *$

$-1.040 * * *$

$-0.347^{* * *}$

$-0.932 * * *$

$-0.370 * * *$

$-0.164^{* * *}$

$-0.266 * * *$

$8.973^{* * *}$

2.786 ***

$11.770^{* * *}$
$1.561^{* * *}$

$1.264^{*}$

$$
\begin{array}{r}
72.420^{* * *} \\
1.529^{* * *} \\
0.861^{* * *} \\
593.500^{* * *} \\
1029.000^{* * *}
\end{array}
$$

$-35.950 * * *$

$0.378^{* * *}$

$0.518^{* * *}$

$-171.000^{* * *}$

$-132.300^{* * *}$

0.026

$-1.790 * * *$

$-1.033^{* * *}$

$-0.357 * * *$

$-0.764 * * *$

$-0.296 * * *$

$-0.359 * * *$

$-0.262 * * *$

8.299 ***

$1.843^{* * *}$

$9.204^{* * *}$

Observations

6,378

6,378 


\section{Fit of the model}

Table A.6: Fit singles and single parents

\begin{tabular}{|c|c|c|c|c|}
\hline & \multirow{2}{*}{$\begin{array}{l}\text { Observed } \\
\text { (1) }\end{array}$} & \multirow{2}{*}{$\begin{array}{c}\text { w/o involuntary UE } \\
(2) \\
\end{array}$} & \multicolumn{2}{|c|}{$\mathrm{w} /$ involuntary UE } \\
\hline & & & $\begin{array}{c}\text { Job search exogeneous } \\
\text { (3) }\end{array}$ & $\begin{array}{c}\text { Job search endogeneous } \\
(4)\end{array}$ \\
\hline \multicolumn{5}{|c|}{ Singles without children } \\
\hline Voluntary UE & 0.10 & 0.15 & 0.10 & 0.10 \\
\hline Involuntary UE & 0.05 & & 0.05 & 0.05 \\
\hline \multicolumn{5}{|l|}{ Hours per week: ${ }^{\mathrm{a}}$} \\
\hline 0 (vol. + invol. UE) & 0.15 & 0.15 & 0.15 & 0.15 \\
\hline 9 & 0.01 & 0.02 & 0.02 & 0.02 \\
\hline 18 & 0.03 & 0.02 & 0.02 & 0.02 \\
\hline 26 & 0.06 & 0.08 & 0.08 & 0.08 \\
\hline 35 & 0.32 & 0.31 & 0.31 & 0.31 \\
\hline 41 & 0.42 & 0.42 & 0.42 & 0.42 \\
\hline \multicolumn{5}{|l|}{ Singles parents } \\
\hline Voluntary UE & 0.20 & 0.27 & 0.20 & 0.20 \\
\hline Involuntary UE & 0.07 & & 0.05 & 0.07 \\
\hline \multicolumn{5}{|l|}{ Hours per week: } \\
\hline 0 (vol. + invol. UE) & 0.27 & 0.27 & 0.26 & 0.25 \\
\hline 9 & 0.02 & 0.03 & 0.02 & 0.02 \\
\hline 18 & 0.08 & 0.07 & 0.07 & 0.07 \\
\hline 26 & 0.18 & 0.19 & 0.19 & 0.19 \\
\hline 35 & 0.28 & 0.28 & 0.28 & 0.27 \\
\hline 41 & 0.16 & 0.17 & 0.17 & 0.16 \\
\hline
\end{tabular}

${ }^{\text {a }}$ Discretized as $0=[0,4], 9=[5,13], 18=[14,21], 26=[22,29], 35=[30,37], 41=[38,$.$) .$ 
Table A.7: Fit couples

\begin{tabular}{|c|c|c|c|}
\hline & $\begin{array}{l}\text { Observed } \\
\qquad(1)\end{array}$ & $\begin{array}{c}\text { w/o involuntary UE } \\
\text { (2) }\end{array}$ & $\begin{array}{c}\text { w/ involuntary UE } \\
\text { Job search exogeneous } \\
(3)\end{array}$ \\
\hline \multicolumn{4}{|c|}{ Men in couples without children } \\
\hline Voluntary UE & 0.04 & 0.05 & 0.03 \\
\hline Involuntary UE & 0.02 & & 0.02 \\
\hline \multicolumn{4}{|l|}{ Hours per week: ${ }^{\mathrm{a}}$} \\
\hline 0 (vol. + invol. UE) & 0.05 & 0.05 & 0.05 \\
\hline 9 & 0.01 & 0.01 & 0.01 \\
\hline 18 & 0.01 & 0.01 & 0.01 \\
\hline 26 & 0.03 & 0.04 & 0.03 \\
\hline 35 & 0.28 & 0.28 & 0.28 \\
\hline 41 & 0.61 & 0.61 & 0.61 \\
\hline \multicolumn{4}{|c|}{ Men in couples with children } \\
\hline Voluntary UE & 0.03 & 0.04 & 0.03 \\
\hline Involuntary UE & 0.01 & & 0.02 \\
\hline \multicolumn{4}{|l|}{ Hours per week: } \\
\hline 0 (vol. + invol. UE) & 0.04 & 0.04 & 0.05 \\
\hline 9 & 0.00 & 0.01 & 0.00 \\
\hline 18 & 0.01 & 0.01 & 0.01 \\
\hline 26 & 0.02 & 0.03 & 0.02 \\
\hline 35 & 0.28 & 0.27 & 0.28 \\
\hline 41 & 0.64 & 0.64 & 0.64 \\
\hline \multicolumn{4}{|c|}{ Women in couples without children } \\
\hline Voluntary UE & 0.21 & 0.24 & 0.19 \\
\hline Involuntary UE & 0.04 & & 0.04 \\
\hline \multicolumn{4}{|l|}{ Hours per week: } \\
\hline 0 (vol. + invol. UE) & 0.25 & 0.24 & 0.22 \\
\hline 9 & 0.05 & 0.06 & 0.06 \\
\hline 18 & 0.13 & 0.11 & 0.11 \\
\hline 26 & 0.17 & 0.20 & 0.20 \\
\hline 35 & 0.27 & 0.24 & 0.24 \\
\hline 41 & 0.13 & 0.14 & 0.14 \\
\hline \multicolumn{4}{|c|}{ Women in couples with children } \\
\hline Voluntary UE & 0.19 & 0.23 & 0.19 \\
\hline Involuntary UE & 0.04 & & 0.03 \\
\hline \multicolumn{4}{|l|}{ Hours per week: } \\
\hline 0 (vol. + invol. UE) & 0.23 & 0.23 & 0.22 \\
\hline 9 & 0.08 & 0.09 & 0.09 \\
\hline 18 & 0.26 & 0.25 & 0.25 \\
\hline 26 & 0.26 & 0.27 & 0.27 \\
\hline 35 & 0.13 & 0.12 & 0.12 \\
\hline 41 & 0.04 & 0.04 & 0.05 \\
\hline
\end{tabular}

${ }^{\text {a }}$ Discretized as $0=[0,4], 9=[5,13], 18=[14,21], 26=[22,29], 35=[30,37], 41=[38,)$. 
E Elasticities subgroups 
Table A.8: Elasticities subgroups: singles and single parents

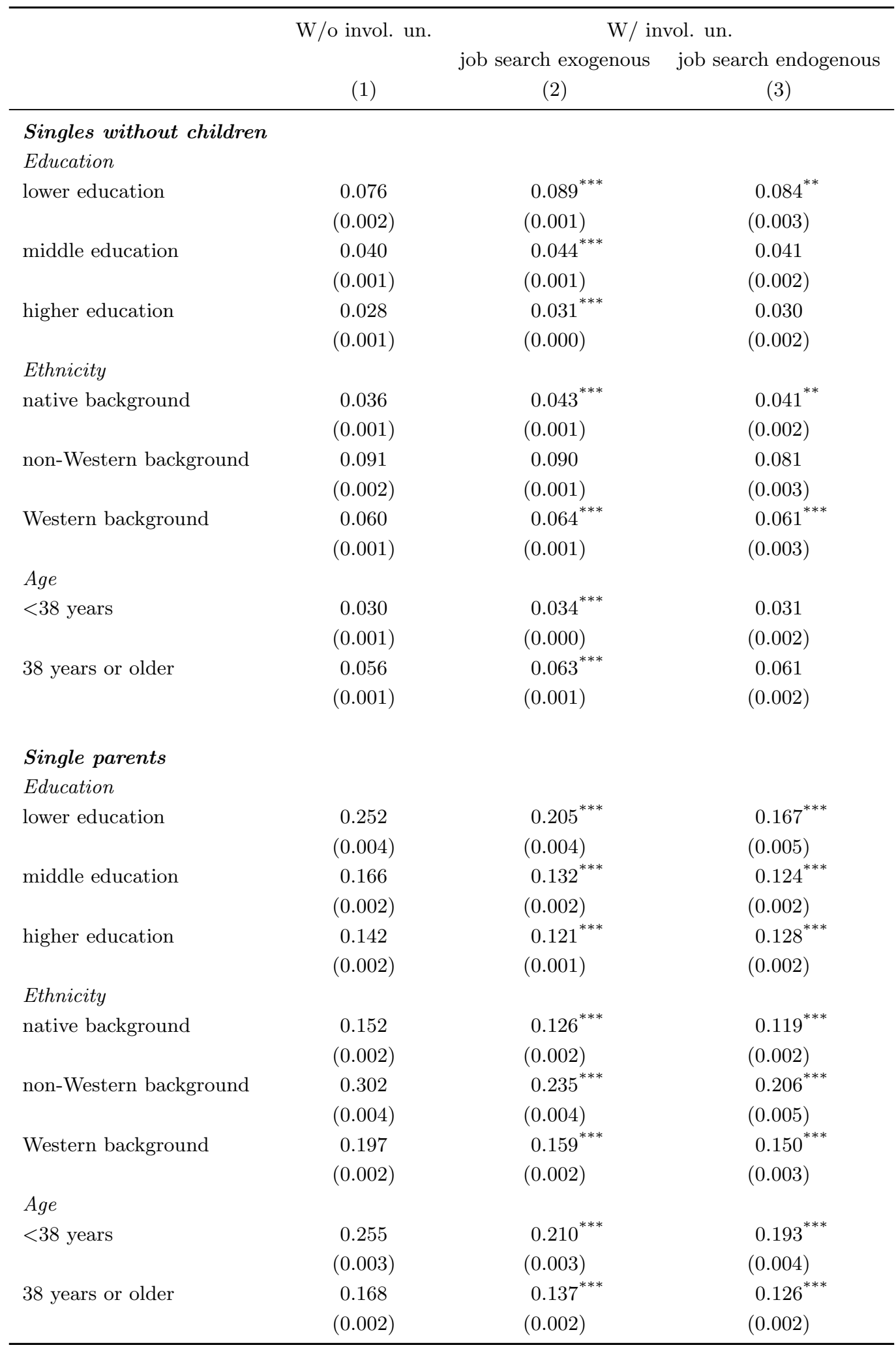

*** Statistically different from the model without involuntary unemployment at the $1 \%$ level.

** Statistically different from the model without involuntary unemployment at the $5 \%$ level. 
Table A.9: Elasticities subgroups: couples

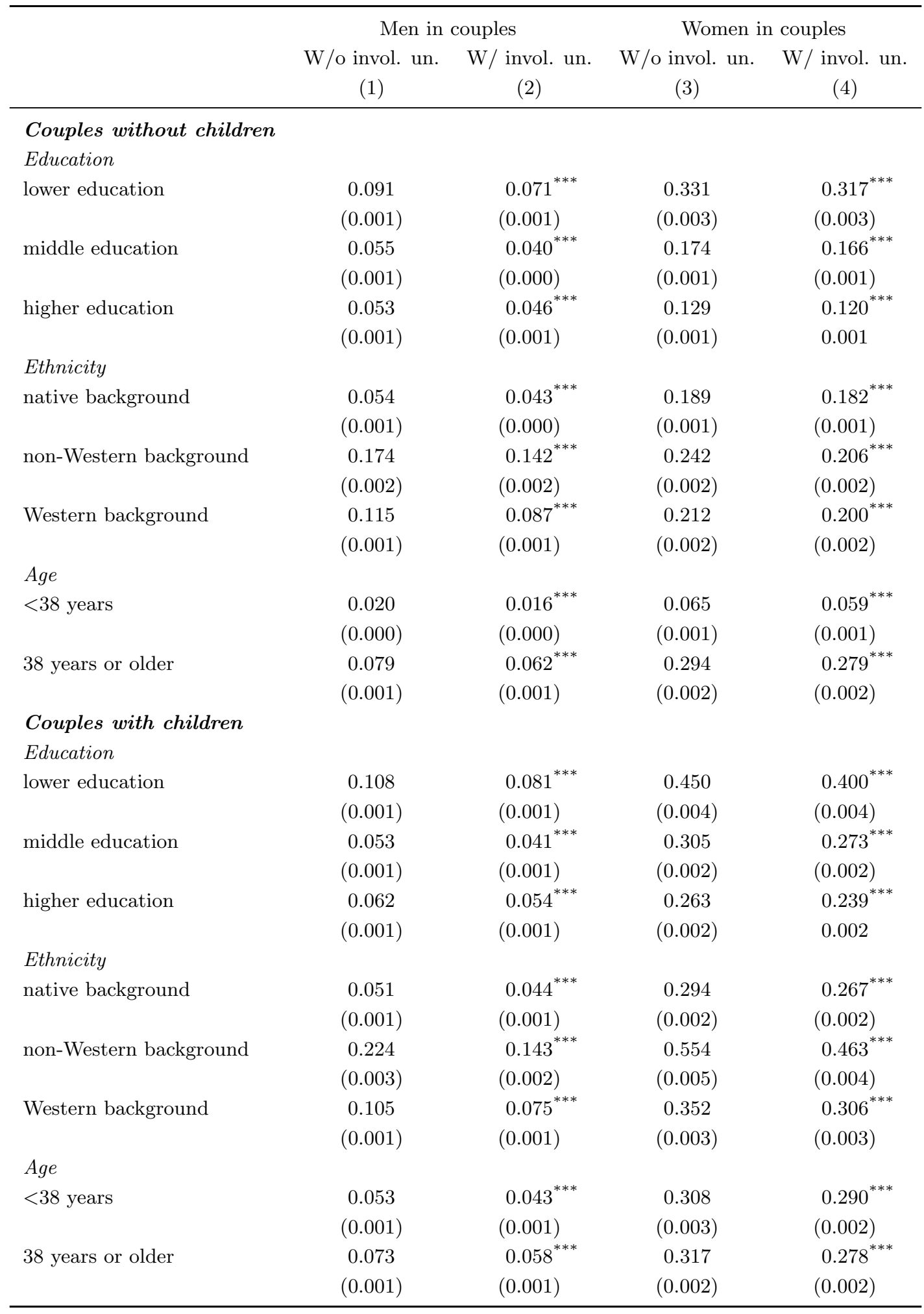

*** Statistically different from the model without involuntary unemployment (at the $1 \%$ level). 

Publisher:

CPB Netherlands Bureau for Economic Policy Analysis

P.O. Box 80510 | 2508 GM The Hague

$\mathrm{T}$ (070) 3383380

September 2015 | ISBN 978-90-5833-703-0 